\title{
Heat transfer enhancement using hybrid nanoparticles in ethylene glycol through a horizontal heated tube
}

\author{
Adnan M. Hussein 1 , M.M. Noor ${ }^{2}$, K. Kadirgama ${ }^{2}$, D. Ramasamy ${ }^{2}$ and \\ M.M. Rahman ${ }^{2}$ \\ ${ }^{1}$ Al-Haweeja Institute, Northern Technical University, Iraq. \\ ${ }^{2}$ Faculty of Mechanical Engineering, Universiti Malaysia Pahang, \\ 26600 Pekan, Pahang, Malaysia. \\ *E-mail: adnanphd2012@gmail.com / muhamad@ump.edu.my
}

\begin{abstract}
Heating hybrid nanofluids by the mixing of solid nanoparticles suspended in liquid represents a new class of heat transfer enhancement. To enhance heat transfer for many industrial applications, a computational fluid dynamics modelling simulation using the finite volume method and adopting the SIMPLE algorithm was performed. The mixture of aluminium nitride nanoparticles into ethylene glycol which acts as a base fluid is considered as a new concept of hybrid nanofluids that can increase heat transfer. The hybrid nanofluid was prepared experimentally with a volume fraction range of $1 \%$ to $4 \%$. The size diameter of nanoparticles, heat flux around a horizontal straight tube, and Reynolds number is approximately $30 \mathrm{~nm}, 5000 \mathrm{w} / \mathrm{m}^{2}$ and 5,000 to 17,000 , respectively. The computational method had been successfully validated using available experimental data reported in the literature. It was found that $1 \%$ to $3 \%$ Aluminum nitride hybrid nanofluids can significantly affect efficiency, while more than $3 \%$ volume fraction are insignificant as they obtain less than one efficiency. Results show that a combination of aluminium nitride nanoparticles with the EG base fluid tends to augment heat transfer performance significantly.
\end{abstract}

Keywords: Nanofluid; hybrid; ethylene glycol; turbulent; CFD.

\section{INTRODUCTION}

Heat transfer enhancement using hybrid nanofluids is a new trend [1-3]. An experimental investigation was conducted by passing a hybrid nanofluid through a double pipe heat exchanger as shown in [4]. It was found that the hybrid nanofluid performance was enhanced up to $35 \%$ in comparison with liquids at high volume concentrations. Experimental studies using other types of nanofluids such as $\mathrm{Cu}, \mathrm{CuO}, \mathrm{Fe}_{2} \mathrm{O}_{3}, \mathrm{Al}_{2} \mathrm{O}_{3}$, $\mathrm{CNT}, \mathrm{SiO}_{2}, \mathrm{TiO}_{2}, \mathrm{SiC}, \mathrm{Ag}$, and zirconia through a tube have been conducted by many researchers [5-13]. Choi [14] prepared a nanofluid by engineering colloids made of a base fluid and nanoparticles. Nanoparticles have thermal conductivities at typically an order of magnitude higher than those of the base fluids and with sizes significantly smaller than $100 \mathrm{~nm}$ [15-18]. The benefit of thermal fluid properties plays an important role in improving equipment heat transfer performance. Nanofluids are a new class of working fluids with the capability to enhance suspension stability and conductivity for various industrial applications [19-22]. Recent interesting discussions have focused on nanocomposite materials in order to find new hybrid nanofluids that give the highest heat 
transfer rates $[23,24]$. $\mathrm{Cu}-\mathrm{Al}_{2} \mathrm{O}_{3} /$ water hybrid nanofluids were synthesized using a twostep method by adopting the hydrogen reduction technique by Suresh et al. [25]. The hybrid nanofluids' volume fractions from $0.1 \%$ to $2 \%$ were prepared by dispersing the synthesized nanocomposite powder in deionized water. Results indicated that both thermal conductivity and viscosity of the prepared hybrid nanofluids increase as the nanoparticles' volume fraction increases. It was found that the increase in viscosity is higher than the increase in the thermal conductivity of hybrid nanofluids. A fully developed laminar convective heat transfer and pressure drop characteristics investigation using a uniformly heated circular tube and $\mathrm{Cu}-\mathrm{Al}_{2} \mathrm{O}_{3} /$ water hybrid nanofluid has been carried out by Suresh et al. [25]. The results showed that the Nusselt number was enhanced by $13.56 \%$ at a Reynolds number of 1730 , compared to the Nusselt number of water. The regression equations between the input and output parameters were in good agreement with the experimental data.

The convective heat transfer of hybrid nanofluid flow through a tubular heat exchanger was experimentally studied on by Madhesh et al. [26]. The hybrid nanofluid was prepared by dispersing copper-titanium nanocomposite in water at $0.1 \%$ to $1.0 \%$ volume fractions. Results showed that the convective heat transfer coefficient increased by $48.4 \%$ for up to $0.7 \%$ of the volume fraction of the hybrid nanofluid. The effect of the functionalisation method on the stability and thermal conductivity of CNT- Alumina hybrid nanofluid was investigated on by Abbasi et al. [27]. The thermal conductivities of different hybrid nanofluids were measured using a modified transient hot wire method. Results showed that functional groups have a significant influence on the thermal conductivity of hybrid nanofluids. Thermal conductivity improved up to $20.68 \%$ at a $0.1 \%$ volume concentration of hybrid nanofluid. Mosayebidorcheh et al. [28] studied the turbulent nanofluid heat transfer in the presence of a magnetic field. Results illustrated that the Nusselt number increases linearly with the Reynolds number, nanoparticle volume fraction and turbulent Eckert number, while it is inversely proportional with the Hartmann number and turbulent parameter. Labib et al. [29] selected a two-phase mixture model to study hybrid nanofluid convective heat transfer. They employed two different base fluids individually to investigate their effect on convective heat transfer mixing of Alumina nanoparticles. Results indicated that the use of EG as base fluid gives better heat transfer augmentation than that of water. A comparison of the computational model for CNTs/water nanofluid was conducted in order for it to be validated using available data in the literature. Sundar et al. [30] studied turbulent heat transfer of hybrid nanofluids flowing through a circular tube. The $\mathrm{Fe}_{3} \mathrm{O}_{4} / \mathrm{MWCNT}$ nanocomposites were prepared by in-situ method which included the dispersion of carboxylated carbon nanotubes in distilled water and the mixing of ferrous chloride and ferric chloride. Results showed that heat transfer was enhanced by $31.10 \%$ with a penalty of 1.18-times increase of pumping power for a particle loading of $0.3 \%$ at a Reynolds number of 22,000 as compared to base fluid data. The correlation equations proposed for the input and output parameters were in good agreement with the experimental data. Baby and Ramaprabhu [31] synthesized $\mathrm{Fe}_{3} \mathrm{O}_{4} / \mathrm{MWNTs}$ and $\mathrm{Fe}_{3} \mathrm{O}_{4}-\mathrm{SiO}_{2} / \mathrm{MWNTs}$ using a simple chemical reduction technique and dispersed it in water using ultrasonication. It was observed that $\mathrm{Fe}_{3} \mathrm{O}_{4} / \mathrm{MWNTs}$ with surfactant and $\mathrm{Fe}_{3} \mathrm{O}_{4}-\mathrm{SiO}_{2} / \mathrm{MWNTs}$ without surfactant at $0.03 \%$ volume concentrations of a magnetic field improve thermal conductivity by $20 \%$ and $24.5 \%$, respectively.

The present article studies the heat transfer and pressure drop characteristics of hybrid nanofluids under turbulent flow conditions in a circular tube. This article proves the heat transfer enhancement and pressure drop of hybrid nanofluids using CFD analysis 
by commercial software. The two nanocomposites used in this work are aluminium and nitride from $1 \%$ to $4 \%$ volume fractions dispersed in EG as a base fluid.

\section{METHODS AND MATERIALS}

\section{Nanofluid Preparation}

The nanofluids were prepared in a thermal laboratory of the Faculty of Mechanical Engineering, University Malaysia Pahang. Nanopowders were purchased from US Research Nanomaterials, Inc. (NovaScientific Resources (M) Sdn. Bhd). Measured quantities of nanoparticles were dispersed in EG to obtain mass concentration nanofluids. A mechanical stirrer was used to achieve a homogenously dispersed solution. This method was done according to [32] and then subjected to ultrasonic for at least $3 \mathrm{hrs}$ to break up any residual agglomerations. The mass of the nanoparticles $\left(m_{p}\right)$ and EG $\left(m_{f}\right)$ were measured accurately $(0.001 \mathrm{~g})$. The sedimentation of nanoparticles at the bottom of the samples showed the changes in physical properties of the bulk nanofluids with time [33]. In the case undertaken, the measurement of nanofluids' thermal properties require many individual measurements for at least one month in order to check for sample stability. Samples were checked after the conclusion of each test was finished but no visible sedimentation was found. The transient hot-wires method shown in Figure 1(a) was used to measure the thermal conductivity of nanofluids experimentally. The wire was placed along the axis of a container and surrounded by the nanofluid in order to measure the nanofluid's thermal conductivity. Platinum has a high electrical resistivity; i.e., 1.06 $\times 10^{-7} \Omega \mathrm{m}\left(\right.$ at $\left.20^{\circ} \mathrm{C}\right)$, an order of magnitude higher than that of other metals.

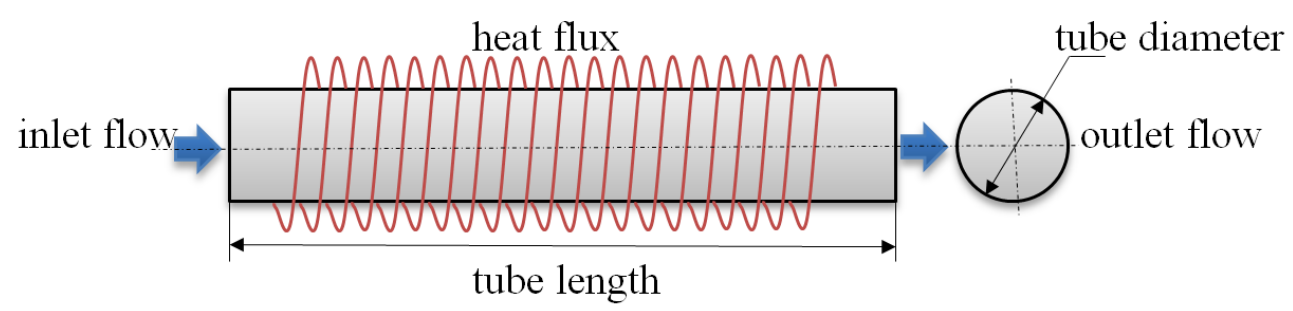

(a) Schematic diagram of physical model

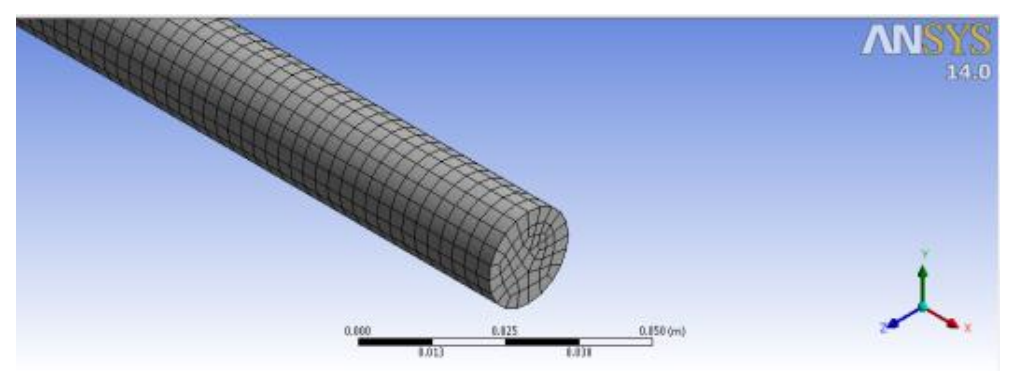

(b) Meshing surfaces

Figure 1. Geometry and grid computational model.

In addition, platinum has a temperature coefficient of resistance of $0.0003925^{\circ} \mathrm{C}^{-1}$ (for pure platinum) which is much higher than that of other metals available to be chosen as wire material. The wire was also used as a line heat source, thus the wire's diameter was kept within $100 \mu \mathrm{m}$. The length of the wire was kept to just a few centimetres 
compared to the wire's diameter which represents an infinitely long line heat source so as to assure a directional (radial) heat transfer. Calibration was conducted using a standard fluid (glycerine) which was already brought with the device. The error between reading data and the standard was 0.0023 . After verification was performed using pure EG and compared with the standard, the error between them was 0.0014 [2]. Viscosity is an important indication in evaluating the thermal properties of nanofluids. A commercial Brookfield DV-I prime viscometer was used to measure viscosity at different temperatures and rotor RPMs as shown in Figure 1(b). Base fluid ethylene glycol (EG) was used to measure viscosity for calibration purposes. After that, the experimented nanofluid was used to measure viscosity.

\section{Thermal properties}

The masses of nanoparticles $\left(m_{p}\right)$ and EG $\left(m_{f}\right)$ were measured accurately $(0.001 \mathrm{~g})$ to estimate the weight percentage $(\varphi)$ by using Eq. (1) $[34,35]$ :

$$
\varphi=\left(\frac{m_{p}}{\left(m_{p}+m_{f}\right)}\right) \times 100
$$

Equation (2) was used to estimate the volume fraction of the nanofluid $\phi$ depending on the nanoparticles' density $\left(\rho_{p}\right)$ and base fluid density $\left(\rho_{f}\right)$ at $25^{\circ} \mathrm{C}$.

$$
\phi=\frac{\frac{m_{p}}{\rho_{p}}}{\frac{m_{p}}{\rho_{p}}+\frac{m_{f}}{\rho_{f}}}
$$

The $\mathrm{pH}$ values of the nanofluid were measured using an OAKTON device for the nanofluid volume fractions of $1 \%$ to $4 \%$. The $\mathrm{pH}$ values before and after experimental tests refer to the nanofluids stability and changes in thermophysical properties. If the $\mathrm{pH}$ values of a suspension decrease, the force among particles will increase and the movement of the nanoparticle suspension enhances the heat transfer process. In order to augment heat transfer for many applications, the $\mathrm{pH}$ of the nanofluids should be kept at low values [36]. The hybrid mixture of aluminium nanopowders and nitrides suspended in EG nanofluids were considered as a single-phase flow incompressible Newtonian fluid. The isotropic and thermal properties of aluminium and nitride nanopowders are shown in Table 1.

Table 1. Thermal properties.

\begin{tabular}{lcc}
\hline Property & EG & Aluminum nitride (AlN) \\
\hline Density $\left(\mathrm{kg} / \mathrm{m}^{3}\right)$ & 1101 & 3260 \\
Specific heat $(\mathrm{J} / \mathrm{kg} . \mathrm{K})$ & 2382 & 735 \\
Thermal conductivity (W/m.K) & 0.256 & 180 \\
Viscosity (kg/m.s) & 0.0095 & - \\
\hline
\end{tabular}




\section{Simulation Process}

The forced convection of a hybrid nanofluid consisting of EG and AlN nanopowders through a straight horizontal tube with $27 \mathrm{~nm}$ size diameter and $5000 \mathrm{~W} / \mathrm{m}^{2}$ uniform heat flux around the tube wall was employed under turbulent conditions. The schematic diagram of the physical model shown in Figure 2 represents a two-dimensional nanofluid flow through a circular horizontal tube with a length of $2000 \mathrm{~mm}$. In this study, rectangular cells were used as the meshing surfaces of the tube wall as shown in Figure 2.

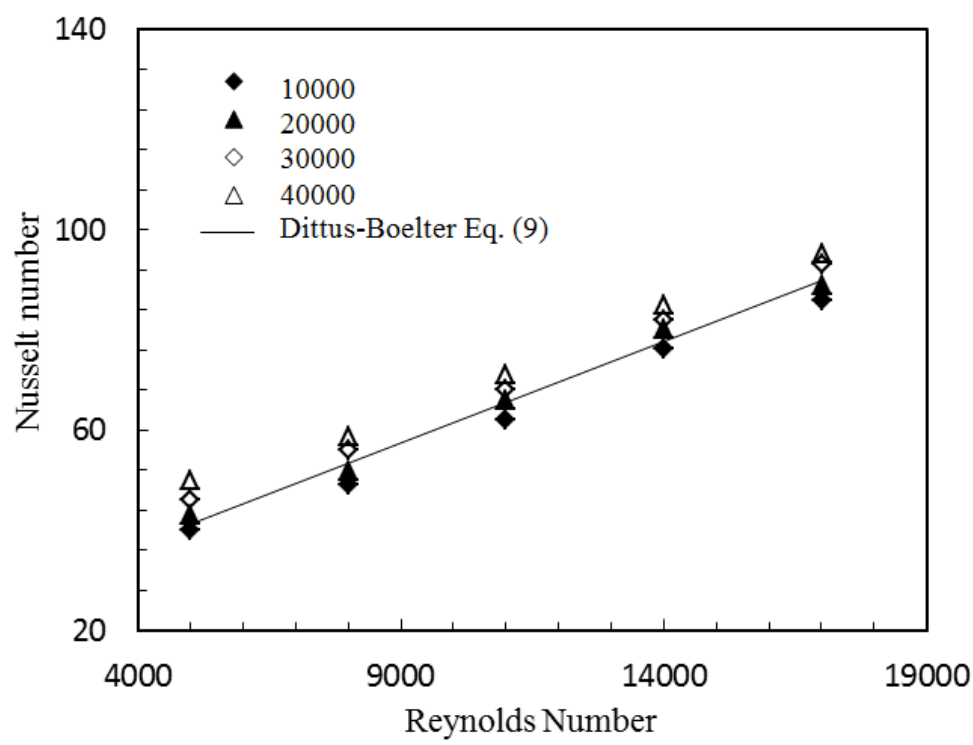

Figure 2. Grid independent test.

The diameter and thickness of the tube is $19 \mathrm{~mm}$ and $2 \mathrm{~mm}$, respectively. It is similar in geometry to the numerical work used by [34] who numerically investigated the turbulent convective heat transfer and pressure drop characteristics of $\mathrm{TiO}_{2} /$ water nanofluid inside a circular tube. The model assumed that the flow is steady, turbulent, and symmetrical with respect to the horizontal plane passing through the circular tube. For all these assumptions, the dimensional conservation equations are the continuity, momentum, and energy equations [35]:

$$
\begin{gathered}
\frac{\partial u}{\partial x}+\frac{\partial u}{\partial y}=0 \\
u \frac{\partial u}{\partial x}+v \frac{\partial u}{\partial y}=-\frac{1}{\rho} \frac{\partial P}{\partial x}+v \frac{\partial^{2} u}{\partial x^{2}} \\
u \frac{\partial T}{\partial x}+v \frac{\partial T}{\partial y}=\alpha \frac{\partial^{2} T}{\partial x^{2}}
\end{gathered}
$$

A high Reynolds number was included as an input parameter, the pressure treatment adopted used the SIMPLE scheme, and a turbulent viscous $k$ - $\varepsilon$ model was also used. The solutions were considered to be converged at residuals lower than $10^{-6}$. The simulation results were compared to equations for the friction factor (8) and Nusselt number (9) correlated by Blasius and Dittus-Boelter respectively [6, 35]: 


$$
\begin{gathered}
f=\frac{0.316}{R e^{0.25}} \\
N u=0.023 \times R e^{0.8} \times P r^{0.4}
\end{gathered}
$$

The percentages of heat transfer enhancement and efficiency depending on the nanofluid and base fluid used were evaluated as [35]:

$$
\begin{gathered}
E \%=\frac{N u_{n f}-N u_{f}}{N u_{n f}} \times 100 \\
\eta=\left(\frac{N u_{n f}}{N u_{f}}\right) /\left(\frac{f_{n f}}{f_{f}}\right)^{1 / 3}
\end{gathered}
$$

\section{Boundary Conditions}

The volume fractions of the AlN-EG hybrid nanofluid used as the input fluid were 1, 2, 3 , and $4 \%$ with an inlet temperature of $30{ }^{\circ} \mathrm{C}$. EG was used as the working fluid for comparison purposes and a CFD analysis was performed with a uniform velocity profile at the inlet and a pressure outlet condition at the outlet regions. The tube was assumed to have perfectly smooth walls and the Reynolds number was varied from 5000 to 17000 at each iteration step as input data.

\section{Grid Independence Test}

The grid independence test was performed using the ANSYS software and it was found that 20000 cells $(2000 \times 10)$ was the best size of mesh, thus was adopted as the optimum meshing size. Four different meshing sizes were considered; 10000 cells $(1000 \times 10)$, 20000 cells $(2000 \times 10), 30000$ cells $(1000 \times 30)$ and 40000 cells $(2000 \times 20)$ for EG to check grid sizing. A comparison of the Nusselt number for all four meshing sizes using the Dittus-Boelter Eq. (9) showed good agreement with a maximum deviation of not more than 5\% (see Figure 2). It can be seen that all of the meshing sizes chosen could have been used but the 20000 cells meshing size was considered the optimum meshing size due to its best accuracy.

\section{CFD Analysis}

CFD simulations were performed using the ANSYS software with solver strategy. The governing single-phase conservation equations were solved using the control volume approach. The simulation results were compared to the predicted results of [28-30] and [34]. The simulation study consisted of building a geometry construction of a circular tube and meshing to create a physical model, choosing boundary conditions, and finally setup and solving. All scalar values and velocity components of the problem were calculated at the centre of the control volume interface where grid schemes were used intensively. Residuals appeared throughout the iterative process. Finally, the results were obtained when the solution converged, defined by a set of convergence criteria. The Nusselt number and pressure drop inside the circular tube were determined throughout the computational domain in the post-process stage.

\section{RESULTS AND DISCUSSION}

\section{Validation}

The CFD analysis was successfully validated with experimental data reported by Hejazian et al. [36] and Sundar \& Sharma [37] for $\mathrm{Al}_{2} \mathrm{O}_{3}$ /water under turbulent flow conditions as shown in Figure 3. Likewise, the CFD results were compared to the numerical data of 
Bianco et al. [38] and Bianco et al. [39] under turbulent flow conditions for $\mathrm{Al}_{2} \mathrm{O}_{3} /$ water nanofluid through a circular tube. It can be seen that the maximum deviations between the experimental and numerical results of the friction factor and Nusselt number did not exceed $8 \%$.

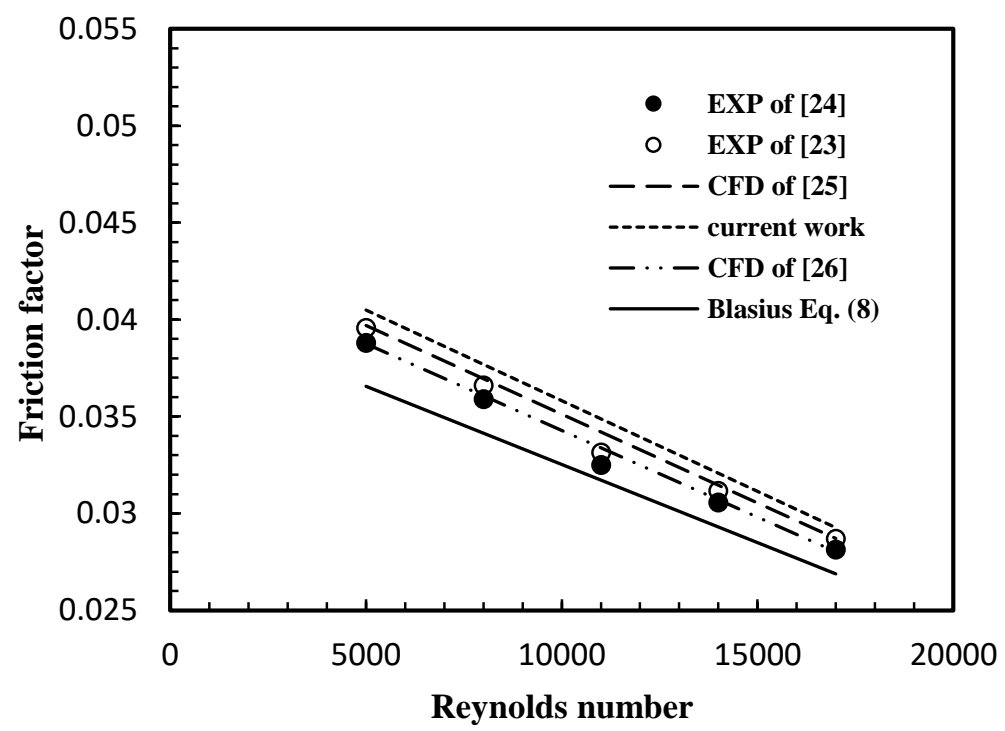

(a) Friction factor

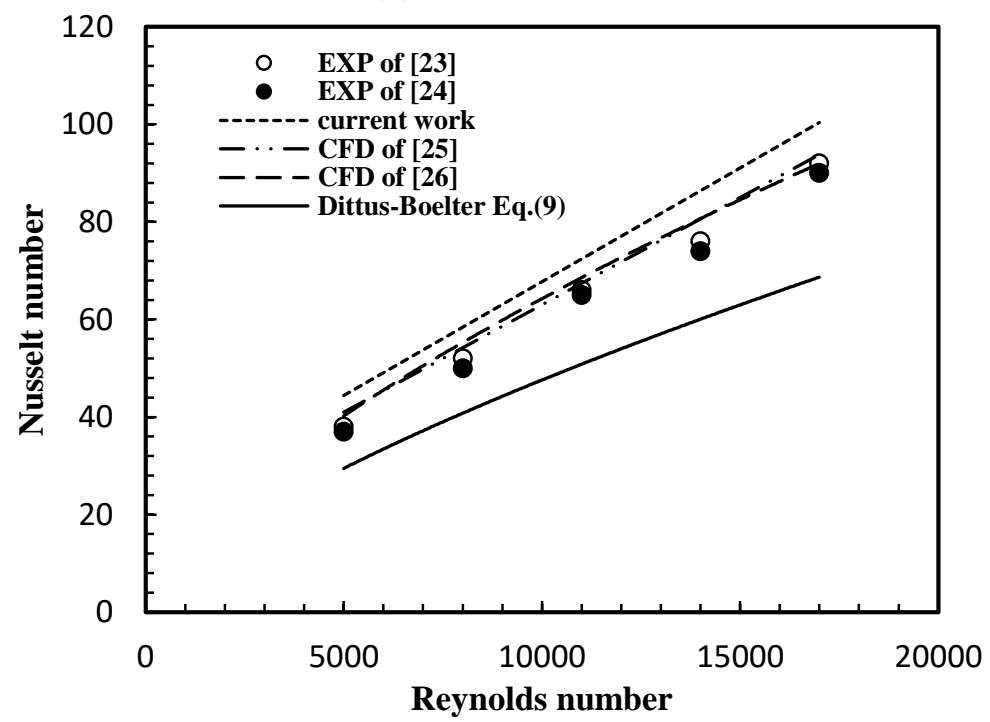

(b) Nusselt number

Figure 3. Validation of the friction factor and Nusselt number.

\section{Pressure Drop}

In order to apply hybrid nanofluids in industrial applications, pressure drop should be investigated with Nusselt number inherently. The CFD data of pressure drop against Reynolds number are illustrated in Figure 4. It can be noted that the pressure drop increased by $13 \%$ with an increase in Reynolds number due to the increase of velocity inside the tube. Likewise, the pressure drop increased by $14 \%$ with an increase of the hybrid nanofluid volume fraction due to the increase in viscosity of the hybrid nanofluid. Meanwhile, the hybrid nanofluid incurred a little penalty in the pressure drop. The numerical data on pressure drop in this study are in good agreement with [36] and [40]. 


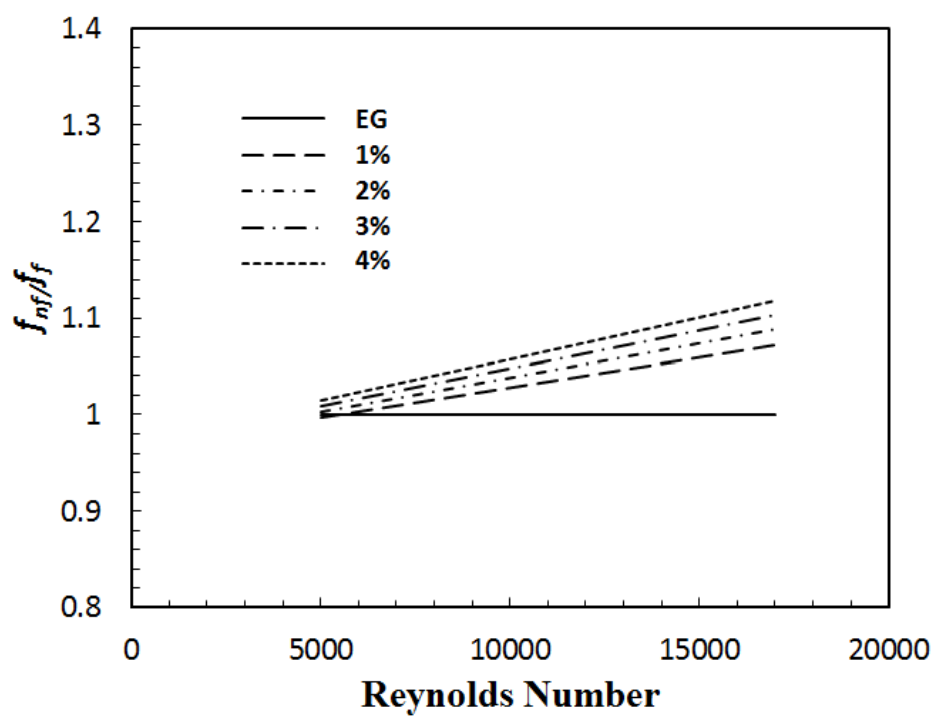

Figure 4. The friction factor ratio at different Reynolds numbers.

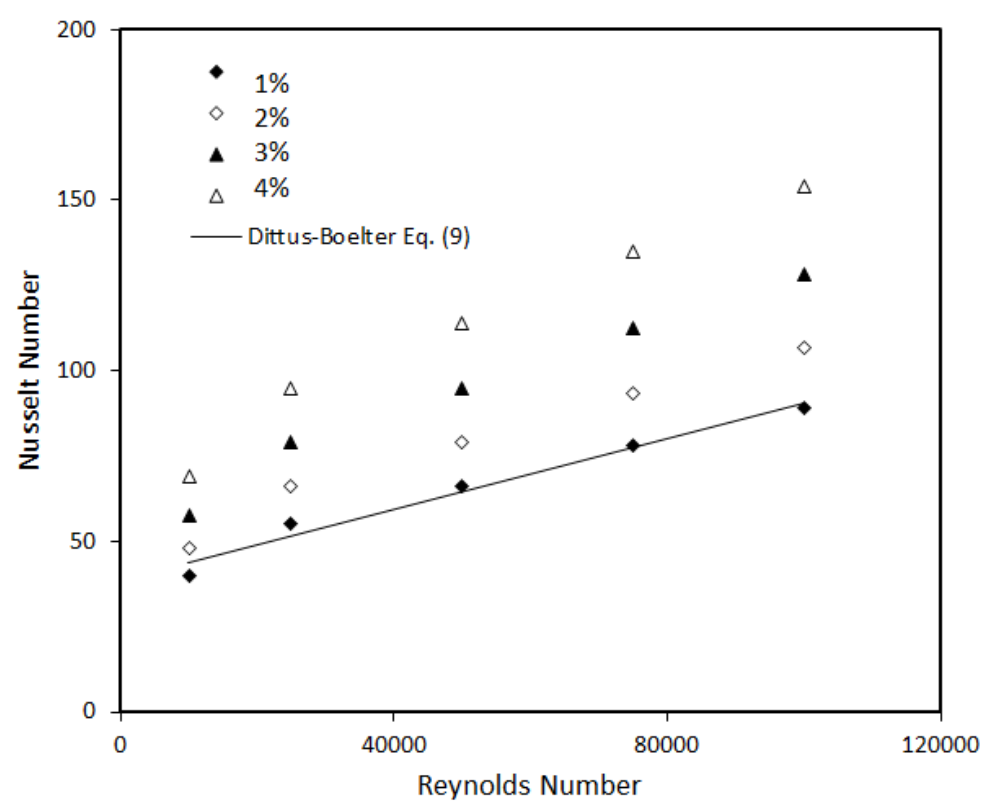

Figure 5. Nusselt number at different Reynolds numbers.

\section{Nusselt Number}

Figure 5 shows the ratio of the hybrid nanofluid's Nusselt number to that of the base fluid at different Reynolds numbers. It can be seen that there was a significant increase of Nusselt number with the increase in Reynolds number. In this CFD analysis, the maximum heat transfer enhancement achieved was about 1.5 for $3 \%$ of hybrid nanopowder volume fraction in EG at a Reynolds number of 17000. The Nusselt number values for the hybrid nanofluid were up to $50 \%$ higher than the values gained for EG flows in the circular tube. The results are similar to the Nusselt number enhancement of $\mathrm{Al}_{2} \mathrm{O}_{3}$ /water nanofluid at different volume fractions achieved by Hejazian et al. [36] and Heyhat et al. [40]. It can be said that heat transfer enhancement using hybrid nanofluid volume fractions agree with the literature results of [36] and [40]. A numerical study by 
[34] reported an increase in Nusselt number at $13.6 \%$ for $\mathrm{TiO}_{2} /$ water using the same geometry. The benefit of using AlN hybrid nanofluids in a horizontal circular tube is significantly clear compared to using the $\mathrm{TiO}_{2} /$ water nanofluid.

\section{Heat transfer enhancement}

Figure 6 shows the heat transfer enhancement with the nanofluid volume fractions. It was observed that the heat transfer enhancement obtained ranged from $28 \%$ to $50 \%$ at hybrid nanoparticles' volume fractions of $1 \%$ to $3 \%$, respectively, whereas, $33 \%$ of heat transfer enhancement was observed at the $4 \%$ hybrid nanofluid volume fraction. The CFD analysis of the heat transfer enhancement appeared to have slightly closer results to the experimental data of [36] and [40] for the $\mathrm{Al}_{2} \mathrm{O}_{3} /$ water nanoparticle volume fractions under turbulent flow conditions inside a circular tube.

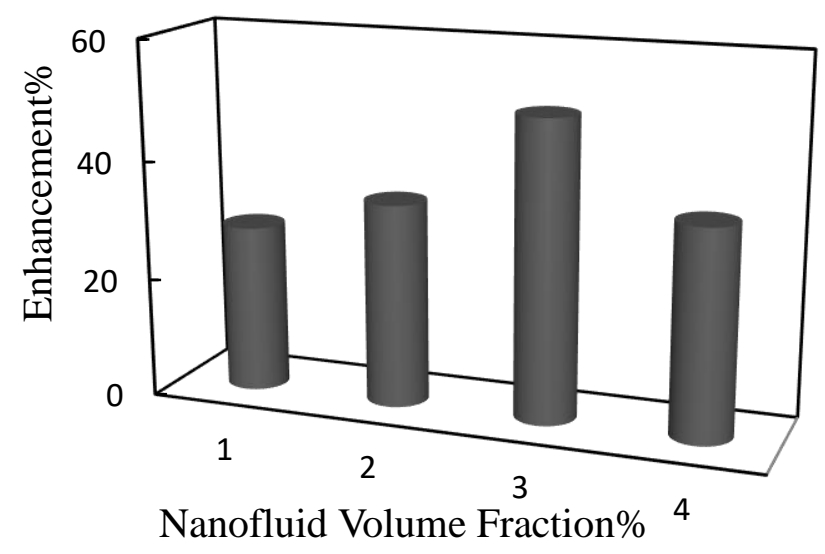

Figure 6. The heat transfer enhancement at different hybrid nanofluid volume fractions.

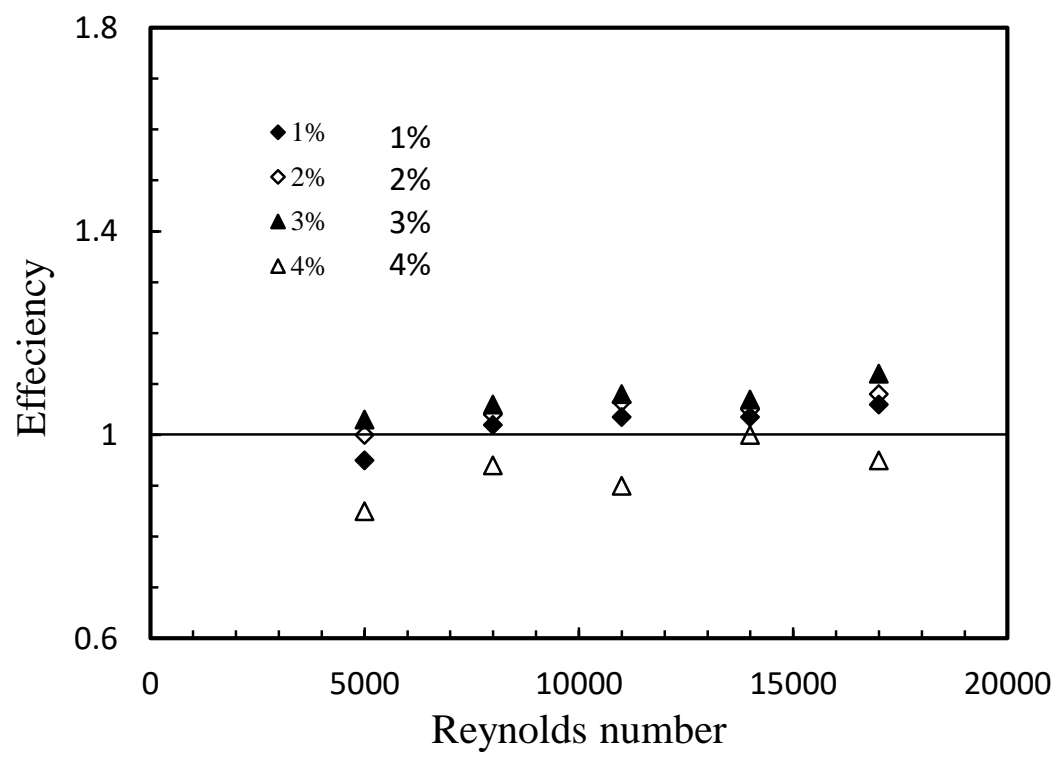

Figure 7. The efficiency of hybrid nanofluids at different Reynolds numbers.

\section{Efficiency}

Both the friction factor and Nusselt number do enhance heat transfer. Therefore, the overall efficiency of heat transfer enhancement for various volume fractions of the hybrid 
nanofluid against their Reynolds numbers is shown in Figure 7. It can be seen that there is a net energy gain for cases where the heat transfer enhancement is greater than one. Therefore, it can be said that the use of $1 \%$ to $3 \%$ hybrid nanofluids is significant with respect to both heat transfer and friction factor, while using more than $3 \%$ volume fractions gives insignificant results as the readings obtained less than one efficiency. The reason for the insignificance is due to the pressure drop which needs a high pumping power through the circular tube. The study's thermal efficiency results are in agreement with Darzi et al.'s [41] results for heat transfer augmentation using $\mathrm{Al}_{2} \mathrm{O}_{3} /$ water nanoparticles which is higher than the pressure drop penalty.

\section{CONCLUSIONS}

In this study, a CFD analysis was conducted to investigate the effect of AlN hybrid nanopowders on heat transfer and pressure drop inside a horizontal circular tube. A grid independence test was performed using the ANSYS/FLUENT software, and the 20000 cells (2000x 10) mesh was adopted as the optimum meshing size. The CFD analysis was successfully validated with experimental and numerical results reported in the literature [36-39]. Obviously, the pressure drop grew as the Reynolds number and nanofluid volume fractions increased. It was observed that the maximum values of Nusselt number ratio for the $3 \%$ hybrid nanofluid were up to $50 \%$ higher than the values gained for EG flows through the circular tube, whereas low values of Nusselt number were observed for the $4 \%$ hybrid nanofluid volume fraction. The heat transfer enhancement obtained was from $28 \%$ to $50 \%$ at the $1 \%$ to $3 \%$ AlN nanoparticle volume fractions respectively, whereas $33 \%$ heat transfer enhancement was observed for the $4 \%$ hybrid nanofluid volume fraction. It was found that the use of $1 \%$ to $3 \%$ AlN hybrid nanofluids was significant with respect to efficiency, while more than $3 \%$ volume fraction was insignificant due to obtaining less than one efficiency.

\section{ACKNOWLEDGMENTS}

The support by the staff of University Malaysia Pahang to the authors is gratefully acknowledged.

\section{REFERENCES}

[1] Wang J, Zhu J, Zhang X, Chen Y. Heat transfer and pressure drop of nanofluids containing carbon nanotubes in laminar flows. Experimental Thermal and Fluid Science. 2013;44:716-21.

[2] Hussein AM, Sharma K, Bakar R, Kadirgama K. The effect of nanofluid volume concentration on heat transfer and friction factor inside a horizontal tube. Journal of Nanomaterials. 2013;2013:1.

[3] Prasad PD, Gupta A, Deepak K. Investigation of trapezoidal-cut twisted tape insert in a double pipe u-tube heat exchanger using al2o3/water nanofluid. Procedia Materials Science. 2015;10:50-63.

[4] Hussein AM. Thermal performance and thermal properties of hybrid nanofluid laminar flow in a double pipe heat exchanger. Experimental Thermal and Fluid Science. 2017. 
[5] Leong K, Saidur R, Kazi S, Mamun A. Performance investigation of an automotive car radiator operated with nanofluid-based coolants (nanofluid as a coolant in a radiator). Applied Thermal Engineering. 2010;30:2685-92.

[6] Reddy VK, Somanchi NS, Devi SR, Gugulothu R, Kumar SP. Heat transfer enhancement in a double pipe heat exchanger using nanofluids. Proceedings of 17th ISME Conference on Advances in Mechanical Engineering, Organized by Department of Mechanical Engineering, Indian Institute of Technology, Delhi on 3-4 October; 2015.

[7] Kourkah FF, Mahd DK, Mirzaee M. Optimization of double pipe heat exchanger with response surface methodology using nanofluid and twisted tape. Fluid Mechanics. 2017;3:20-8.

[8] Siavashi M, Bahrami HRT, Saffari H. Numerical investigation of porous rib arrangement on heat transfer and entropy generation of nanofluid flow in an annulus using a two-phase mixture model. Numerical Heat Transfer, Part A: Applications. 2017;71:1251-73.

[9] Strandberg R, Das DK. Finned tube performance evaluation with nanofluids and conventional heat transfer fluids. International Journal of Thermal Sciences. 2010;49:580-8.

[10] Akhtari M, Haghshenasfard M, Talaie M. Numerical and experimental investigation of heat transfer of $\alpha$-al2o3/water nanofluid in double pipe and shell and tube heat exchangers. Numerical Heat Transfer, Part A: Applications. 2013;63:941-58.

[11] Sahid NSM, Rahman MM, Kadirgama K, Ramasamy D, Maleque MA, Noor MM. Experimental investigation on the performance of the tio 2 and zno hybrid nanocoolant in ethylene glycol mixture towards aa6061-t6 machining. International Journal of Automotive and Mechanical Engineering. 2017;14:391326.

[12] Yusof TM, Arshad AM, Suziyana MD, Chui LG, Basrawi MF. Experimental study of a domestic refrigerator with poe-al2o3 nanolubricant. International Journal of Automotive and Mechanical Engineering. 2015;11:2243-52.

[13] Yogeswaran M, Kadirgama K, Rahman MM, Devarajan R. Temperature analysis when using ethylene-glycol-based tio2 as a new coolant for milling. International Journal of Automotive and Mechanical Engineering. 2015;11:2272-81.

[14] Das SK, Choi SU, Yu W, Pradeep T. Nanofluids: Science and technology: John Wiley \& Sons; 2007.

[15] Sahid NSM, Rahman MM, Kadirgama K. Neural network modeling of grinding parameters of ductile cast iron using minimum quantity lubrication. International Journal of Automotive and Mechanical Engineering. 2015;11:2608-21.

[16] Rahman MM, Kadirgama K. Material removal rate and surface roughness on grinding of ductile cast iron using minimum quantity lubrication. International Journal of Automotive and Mechanical Engineering. 2015;11:2471-283.

[17] Najiha MS, Rahman MM. Experimental study on minimum quantity lubrication in end milling of aa6061-t6 using tialn coated carbide tools. International Journal of Automotive and Mechanical Engineering. 2015;11:2771-85.

[18] Abdolbaqi MK, Azwadi CSN, Mamat R, Azmi WH, Najafi GN. Nanofluids heat transfer enhancement through straight channel under turbulent flow. International Journal of Automotive and Mechanical Engineering. 2015;11:2294-305.

[19] Zainal Abidin S, Mohamad S, Bani Hashim AY, Abdullah N, Hafiz MIM, Masripan $\mathrm{NAB}$, et al. Investigation of thermal characteristics of cnf-based 
nanofluids for electronic cooling applications. Journal of Mechanical Engineering and Sciences. 2016;10:2336-49.

[20] Najiha M, Rahman M, Kadirgama K. Performance of water-based tio2 nanofluid during the minimum quantity lubrication machining of aluminium alloy, aa6061t6. Journal of Cleaner Production. 2016; In press.

[21] Zakaria I, Michael Z, Mohamed WANW, Mamat AMI, Azmi WH, Mamat R, et al. A review of nanofluid adoption in polymer electrolyte membrane (pem) fuel cells as an alternative coolant. Journal of Mechanical Engineering and Sciences. 2015;8:1351-66.

[22] Hussein AM, Sharma KV, Bakar RA, Kadirgama K. Heat transfer enhancement with nanofluids - a review. Journal of Mechanical Engineering and Sciences. 2013;4:452-61.

[23] Haque ME, Bakar RA, Kadirgama K, Noor MM, Shakaib M. Performance of a domestic refrigerator using nanoparticles-based polyolester oil lubricant. Journal of Mechanical Engineering and Sciences. 2016;10:1778-91.

[24] Abdul Hamid K, Azmi WH, Mamat R, Usri NA, Najafi G. Effect of temperature on heat transfer coefficient of titanium dioxide in ethylene glycol-based nanofluid. Journal of Mechanical Engineering and Sciences. 2015;8:1367-75.

[25] Suresh S, Venkitaraj K, Selvakumar P, Chandrasekar M. Synthesis of al 2 o 3$\mathrm{cu} /$ water hybrid nanofluids using two step method and its thermo physical properties. Colloids and Surfaces A: Physicochemical and Engineering Aspects. 2011;388:41-8.

[26] Madhesh D, Kalaiselvam S. Experimental analysis of hybrid nanofluid as a coolant. Procedia Engineering. 2014;97:1667-75.

[27] Abbasi SM, Rashidi A, Nemati A, Arzani K. The effect of functionalisation method on the stability and the thermal conductivity of nanofluid hybrids of carbon nanotubes/gamma alumina. Ceramics International. 2013;39:3885-91.

[28] Mosayebidorcheh S, Sheikholeslami M, Hatami M, Ganji D. Analysis of turbulent mhd couette nanofluid flow and heat transfer using hybrid dtm-fdm. Particuology. 2016;26:95-101.

[29] Labib MN, Nine MJ, Afrianto H, Chung H, Jeong H. Numerical investigation on effect of base fluids and hybrid nanofluid in forced convective heat transfer. International Journal of Thermal Sciences. 2013;71:163-71.

[30] Sundar LS, Singh MK, Sousa AC. Enhanced heat transfer and friction factor of mwcnt-fe 3 o 4/water hybrid nanofluids. International Communications in Heat and Mass Transfer. 2014;52:73-83.

[31] Theres Baby T, Sundara R. Surfactant free magnetic nanofluids based on coreshell type nanoparticle decorated multiwalled carbon nanotubes. Journal of Applied Physics. 2011;110:064325.

[32] Sharma K, Sarm P, Azmi W, Mamat R, Kadirgama K. Correlations to predict friction and forced convection heat transfer coefficients of water based nanofluids for turbulent flow in a tube. International Journal of Microscale and Nanoscale Thermal and Fluid Transport Phenomena. 2012;3:283.

[33] Handbook A. Fundamentals. American Society of Heating, Refrigerating and Air Conditioning Engineers, Atlanta. 2001;111.

[34] Hussein AM, Bakar RA, Kadirgama K, Sharma K. Simulation study of turbulent convective heat transfer enhancement in heated tube flow using tio2-water nanofluid. IOP Conference Series: Materials Science and Engineering: IOP Publishing; 2013. p. 012035. 
[35] Hussein AM, Bakar RA, Kadirgama K, Sharma K. Experimental measurement of nanofluids thermal properties. International Journal of Automotive and Mechanical Engineering. 2013;7:850.

[36] Hejazian M, Moraveji MK, Beheshti A. Comparative study of euler and mixture models for turbulent flow of al 2 o 3 nanofluid inside a horizontal tube. International Communications in Heat and Mass Transfer. 2014;52:152-8.

[37] Sundar LS, Sharma K. Turbulent heat transfer and friction factor of al 2 o 3 nanofluid in circular tube with twisted tape inserts. International Journal of Heat and Mass Transfer. 2010;53:1409-16.

[38] Bianco V, Manca O, Nardini S. Performance analysis of turbulent convection heat transfer of al 2 o 3 water-nanofluid in circular tubes at constant wall temperature. Energy. 2014;77:403-13.

[39] Bianco V, Manca O, Nardini S. Numerical simulation of water/al2o3 nanofluid turbulent convection. Advances in Mechanical Engineering. 2010;2:976254.

[40] Heyhat M, Kowsary F, Rashidi A, Esfehani SAV, Amrollahi A. Experimental investigation of turbulent flow and convective heat transfer characteristics of alumina water nanofluids in fully developed flow regime. International Communications in Heat and Mass Transfer. 2012;39:1272-8.

[41] Darzi AR, Farhadi M, Sedighi K. Heat transfer and flow characteristics of al $2 \mathrm{o}$ 3-water nanofluid in a double tube heat exchanger. International Communications in Heat and Mass Transfer. 2013;47:105-12.

\section{NOMENCLATURES}

$C$ - specific heat capacity $[\mathrm{J} / \mathrm{kg} \mathrm{K}]$

$D$ - diameter [m]

E - enhancement

$f$ - friction factor

$h$ - convection heat transfer coefficient $\left[\mathrm{W} / \mathrm{m}^{2} . \mathrm{K}\right]$

$k$ - thermal conductivity [W/m. K]

$\mathrm{Nu}$ - Nusselt Number $[h D / k]$

$P$ - Pressure $\left[\mathrm{N} / \mathrm{m}^{2}\right]$

$\operatorname{Pr}$ - Prandtle Number $[C \mu / k]$

$R e$ - Renolds Number $[\rho D u / \mu]$

$u$ - Velocity $[\mathrm{m} / \mathrm{s}]$

$\mu$ - Viscosity $\left[\mathrm{N} . \mathrm{s} / \mathrm{m}^{2}\right]$

$\rho$ - Density $\left[\mathrm{kg} / \mathrm{m}^{3}\right]$

$\varphi$ - Volume concentration

$\eta$ - efficiency

\section{Subscripts}

$f \quad$ liquid phases

$p \quad$ solid particle

eff effective nanofluid 